\title{
ResearchArticle
}

\section{Effect of calcium and boron on growth, yield and quality of pomegranate (Punica granatum L.)}

\author{
SUTANU MAJI, ANIRUDDHA YADAV AND K.R. MEENA
}

\begin{abstract}
SUMMARY
A field experiment was conducted to study the effect of foliar application of calcium and boron on vegetative growth, flowering, fruiting and fruit quality of young pomegranate plants cv. BHAGWA. The experiment was set under Randomized Block Design with application of calcium ( 3 and $5 \%)$, boron $(0.25$ and $0.5 \%)$ and their combinations with three replications. The experiment showed that combined application $\left(\mathrm{T}_{6}\right)$ of calcium $(3 \%)$ and boron $(0.25 \%)$ increased plant height at higher rate as compared to their sole application and control. It $\left(\mathrm{T}_{6}\right)$ also produced more number of secondary branches at early stage but, under $\mathrm{T}_{7}$ (calcium $3 \%$ and boron $0.5 \%$ ) at later stages of growth. Although, it was a young orchard, however, flower production was higher under $\mathrm{T}_{6}$ followed by $\mathrm{T}_{7}$ compared to others which was reflected on fruit yield and fruit yield was the highest $\left(359.5 \mathrm{~kg} / \mathrm{ha}\right.$ ) under $\mathrm{T}_{6}$ followed by $\mathrm{T}_{7}$. Fruit weight and fruit size was recorded maximum (77.0 $\mathrm{g}, 6.1 \mathrm{~cm}$ length, $6.00 \mathrm{~cm}$ diameter) under $\mathrm{T}_{7}$. But, other quality parameters like fruit volume $(70 \mathrm{ml})$, specific gravity $(1.10$ $\mathrm{g} / \mathrm{cc})$, TSS $\left(12.57^{\circ} \mathrm{B}\right)$ and sugars $\left(6.66 \%\right.$ Total sugars, $4.73 \%$ reducing sugar) were very good under $\mathrm{T}_{6}$. It is concluded that the combined application of calcium $(3 \%)$ and boron $(0.25 \%)\left(\mathrm{T}_{6}\right)$ could be practiced for good growth, yield and quality fruits of pomegranate.
\end{abstract}

Key Words : Pomegranate, Nutrients, Calcium, Boron, Growth, Flowering, Yield, Quality

How to cite this article : Maji, Sutanu, Yadav, Aniruddha and Meena, K.R. (2017). Effect of calcium and boron on growth, yield and quality of pomegranate (Punica granatum L.). Internat. J. Plant Sci., 12 (2): 108-113, DOI: 10.15740/HAS/IJPS/12.2/ 108-113.

Article chronicle : Received : 01.04.2017; Revised : 19.04.2017; Accepted : 05.05.2017 